\title{
BUILDING A SUSTAINABLE WORLD: ECONOMY INDEX OF GEOPOLYMER CONCRETE
}

Conference Paper · May 2019

CITATION

1

5 authors, including:

Solomon Olakunle Oyebisi

Covenant University Ota Ogun State, Nigeria

50 PUBLICATIONS 122 CITATIONS

SEE PROFILE

Festus Adeyemi Olutoge

University of Ibadan

50 PUBLICATIONS 199 CITATIONS

SEE PROFILE

Some of the authors of this publication are also working on these related projects:

Total cement replacement based absolutely on a fully pozzolanic process View project

Hydrogeology and geotechnical View project
READS

183

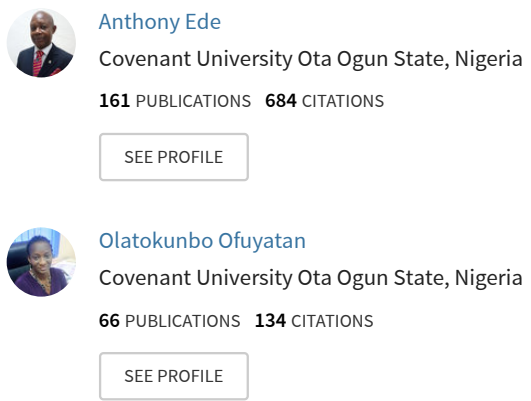




\title{
BUILDING A SUSTAINABLE WORLD: ECONOMY INDEX OF GEOPOLYMER CONCRETE
}

\author{
SOLOMON OYEBISI ${ }^{1}$, ANTHONY EDE ${ }^{1}$, FESTUS OLUTOGE ${ }^{2}$, OLATOKUNBO \\ OFUYATAN $^{1}$, and TOLULOPE ALAYANDE ${ }^{1}$ \\ ${ }^{1}$ Dept of Civil Engineering, Covenant University, Ota, Nigeria \\ ${ }^{2}$ Dept of Civil Engineering, University of Ibadan, Ibadan, Nigeria
}

\begin{abstract}
Geopolymer concrete offers a considerable solution not only to the environmental problem but also to the structural deterioration confronting the world. But, limited or no study is found on its cost implications. Consequently, this study evaluates the production cost and the economy index of geopolymer concrete (GPC) and compares it with the Portland cement concrete (PCC). Corncob ash (CCA) and ground granulated blast furnace slag (GGBFS) were used as source materials in the production of geopolymer concrete. Alkaline liquids were prepared to obtain 12 molar concentrations. The concentration was used to activate the source materials. Grade 30 concrete (M30) was adopted as a mix design proportion. GGBFS was replaced by CCA in varying percentages as $0 \%, 20 \%, 40 \%, 60 \%, 80 \%$, and $100 \%$. The research findings reveal that GPC is $27.71 \%$ lesser than the PCC in terms of production cost while the economy index of GPC is higher than the PCC for the same grade of concrete. The results infer that GPC is cheaper and more viable than the PCC. Thus, geopolymer concrete proves to be an innovative product and appears to be a feasible solution not only to the environmental and structural deteriorating problems but also to the problem of high cost of Portland cement in the construction industry.
\end{abstract}

Keywords: Corncob ash, Ground granulated blast furnace slag, Sodium hydroxide, Sodium silicate, Compressive strength, Regression model.

\section{INTRODUCTION}

The high price of Portland cement and failure to utilize the truly indigenous and eco-friendly materials have not solved the consistent yearning for sustainable housing delivery. Thus, a more eco-friendly and sustainable construction process can be implemented with the introduction of geopolymer technologies that allow the production of concrete without Portland limestone cement. Geopolymer concrete is an inorganic chemical reaction between the source materials that are rich in silica and alumina (such as fly ash, metakaolin, and ground granulated blast furnace slag) and the alkaline activators (Lloyd and Rangan 2010). The most commonly used alkaline activators are sodium hydroxide $(\mathrm{NaOH})$ and sodium silicate $\left(\mathrm{Na}_{2} \mathrm{SiO}_{3}\right)$ (Davidovits 2013, Lloyd and Rangan 2010). The interest in the application of eco-friendly concrete is further necessitated by the global concern for the environment, in terms of sustainable development, reduction in energy consumption and greenhouse gas emissions (Raheem et al. 2010, Oyebisi et al. 2017, Ofuyatan et al. 2018a, Ofuyatan et al. 2018b, Oyebisi et al. 2018a, Oyebisi et al. 2018b, Oyebisi et al. 2018c). Portland cement (PC) production contributes $7 \%$ of the total greenhouse gas emissions to the earth's atmosphere. In comparison, there are about $70-80 \%$ less carbon dioxide 
emissions and 43-59\% less energy required in the production of geopolymer cement, slag byproduct (Davidovits 2013). Hence, the application of geopolymer concrete can significantly reduce the emissions of carbon dioxide into the atmosphere.

Many studies have been conducted on geopolymer concrete two decades ago with limited or no study on its cost implications. Even though, the available ones with cost analyses remain as "grey box". Malathy (2009) estimated that GPC is 10-25\% cheaper than the PCC but mix design ratio, curing type, and concentration of alkaline activators was not stated. Thaarrini and Dhirva (2016) evaluated the comparative study on the production cost of Portland cement concrete and geopolymer concrete. It was discovered that cost of production of geopolymer concrete for grade 30 mix proportion is $1.7 \%$ marginally higher than the Portland cement concrete of the same grade. Also, the production cost of geopolymer concrete for grade $50 \mathrm{mix}$ proportion is $11 \%$ higher than Portland cement concrete of the same grade. Based on these results, type of alkaline activators, the rate of sodium hydroxide concentration, and curing type were not specified. Saurabh and Yogesh (2017) compared the geopolymer concrete with Portland cement concrete based on the strength and cost. The study concluded that production cost per cubic meter $\left(\mathrm{m}^{3}\right)$ of geopolymer concrete is $34.75 \%$ less than the Portland cement concrete of the same grade. But, the rate of sodium hydroxide concentration was not clearly expressed.

The prime yardstick which determines the structural behavior of any concrete is a compressive strength (Rajarajeswari and Dhinakaran 2016) and this can be measured with the cost of concrete to evaluate feasibility. This is referred to as an economy index. Therefore, this study presents the economy index of geopolymer concrete and compares its result with the Portland cement concrete using the characteristic compressive strength as a strength yardstick and the current market prices relating to the material costs to determine the total cost of the concrete. 12 molar concentration of sodium hydroxide and grade $30 \mathrm{mix}$ design ratio were selected and the prediction equations suitable for the relationship between compressive strength and economy index of geopolymer concrete was presented. The optimum scope of the chemistry laboratory procedures, mixture proportions and designs were chosen based on the relevant standards and codes. All the experimental works in this study were carried out at the Civil Engineering Department, Covenant University, Ota, Nigeria.

\section{MATERIALS AND METHODS}

\subsection{Materials}

The following materials were used as fresh concrete mixture constituents namely, Dangote $3 \mathrm{X}$ Portland-limestone cement, corncob ash, granulated blast furnace slag (GBFS), fine aggregate (FA), $12.5 \mathrm{~mm}$ and $19 \mathrm{~mm}$ coarse aggregates $(\mathrm{CA})$, sodium hydroxide $(\mathrm{NaOH})$ pellet with $99 \%$ purity, sodium silicate $\left(\mathrm{Na}_{2} \mathrm{SiO}_{3}\right)$ solution, naphthalene-based superplasticizer (Conplast- $\mathrm{SP} 430$ ) and water.

\subsection{Experimental Methods}

\subsubsection{Design of concrete mix proportion for grade 30Mpa}

Both the geopolymer concrete and the Portland limestone cement concrete mix proportions were designed in accordance to American Concrete Institute (ACI 214R 2011 and ACI 211.12002 ) to arrive at initial mix proportions taking into considerations, the specific gravities, water absorption capacity, and the moisture contents of materials used. The mix replacement levels are presented in Table 1 while the quantity of mixture proportion for the concrete ingredients is presented in Table 2. 
Table 1. The mix proportions for the concrete.

\begin{tabular}{cccc}
\hline S/N & Ingredient Proportions & Mix No. & Remarks \\
\hline 1 & PCC & PCC & Control sample \\
2 & $100 \%$ GGBFS + 0\% CCA & GPC 1 & \\
3 & $80 \%$ GGBFS + 20\% CCA & GPC 2 & \\
4 & $60 \%$ GGBFS + 40\% CCA & GPC 3 & \\
5 & $40 \%$ GGBFS + 60\% CCA & GPC 4 & \\
6 & $20 \%$ GGBFS + 80\% CCA & GPC 5 & \\
7 & $0 \%$ GGBFS + 100\% CCA & GPC 6 & \\
\hline
\end{tabular}

Note: PCC (Portland cement Concrete); GGBFS (Ground Granulated Blast Furnace Slag); CCA (Corncob Ash); GPC (Geopolymer Concrete)

Table 2. Quantity of concrete ingredients $\left(\mathrm{kg} / \mathrm{m}^{3}\right)$.

\begin{tabular}{lccccccccccc}
\hline Mixture ID & PCC & GGBFS & CCA & CA 1 & CA 2 & FA & SS & SH & SP & AL/B & W/S \\
\hline PCC & 390 & 0 & 0 & 516 & 516 & 675 & NA & NA & 3.9 & 0.54 & - \\
GPC 1 & 0 & 390 & 0 & 516 & 516 & 675 & 150 & 60 & - & 0.54 & 0.26 \\
GPC 2 & 0 & 312 & 78 & 516 & 516 & 675 & 150 & 60 & - & 0.54 & 0.26 \\
GPC 3 & 0 & 234 & 156 & 516 & 516 & 675 & 150 & 60 & - & 0.54 & 0.26 \\
GPC 4 & 0 & 156 & 234 & 516 & 516 & 675 & 150 & 60 & - & 0.54 & 0.26 \\
GPC 5 & 0 & 78 & 312 & 516 & 516 & 675 & 150 & 60 & - & 0.54 & 0.26 \\
GPC 6 & 0 & 0 & 390 & 516 & 516 & 675 & 150 & 60 & - & 0.54 & 0.26 \\
\hline
\end{tabular}

Note: CA 1 (12.5mm Coarse Aggregate size); CA 2 (19mm Coarse Aggregate size); FA (Fine Aggregate); SS (Sodium Silicate solution); SH (Sodium Hydroxide solution); SP (Superplasticizer); AL/B (Alkali Liquid/Binder- for GPC, and Water/Binder- for PCC); W/S (Water-to-Geopolymer Solids ratio).

\subsubsection{Preparation of alkaline liquids, mixing of concrete and testing}

The alkaline liquids were prepared 24 hours prior to the casting of concrete based on the standard chemistry laboratory procedures established by (Rajamane and Jeyalakshmi 2014). The mixing was done for about 5 minutes until a homogenous mixture was obtained. Superplasticizer was administered at $1.0 \%$ by mass of binder (PCC). As in the case of Portland cement concrete, superplasticizer is not required for the production of geopolymer concrete because it has no significant effect on its workability and strength properties (Chindaprasirt 2014, Daniel et al. 2010). All samples were cured at room temperature in ambient condition $\left(23 \pm 5{ }^{\circ} \mathrm{C} ; 60 \% \pm 5 \%\right.$ $\mathrm{RH})$. For each mixture, three samples were prepared for each testing age. Compressive strength was carried out in accordance with British Standards (BS EN 12390-3 2000) and the test on the concrete specimens was done at 28 days curing using a digital compressive testing machine of 2000KN maximum capacity. The economy index of the concrete is calculated using Eq. (1).

$$
\text { Economy Index }=\frac{\text { Compressive Strength }}{\text { Total cost of production }}
$$

\section{RESULTS AND DISCUSSIONS}

\subsection{Production Cost per cubic meter $\left(\mathrm{m}^{3}\right)$ of PCC and GPC}

The production costs per cubic meter for both PCC and GPC are presented in Table 3 and Table 4 respectively. From Table 3, it is shown that the total cost of production for an M30 grade of Portland cement concrete is $\$ 109.59$ with cement appropriating a significant percentage of 53.38 in the production cost. Similarly, Table 4 indicates the total cost of production for an M30 grade of geopolymer concrete as $\$ 79.22$ with sodium hydroxide solution appropriating a significant 
percentage of 37.26 in the production cost. By comparison, it is inferred that the cost of production per cubic meter for an M30 grade of geopolymer concrete is $27.71 \%$ lesser than the Portland cement concrete of the same grade.

Table 3. Production cost for M30 per $\mathrm{m}^{3}$ of PCC.

\begin{tabular}{ccccccc}
\hline S/N & Constituent & $\begin{array}{c}\text { Quantity } \\
\left(\mathbf{k g} / \mathbf{m}^{\mathbf{3}}\right)\end{array}$ & $\begin{array}{c}\text { Unit } \\
\text { Rate } \\
\mathbf{( \$ )}\end{array}$ & $\begin{array}{c}\text { Amount } \\
\mathbf{( \$ )}\end{array}$ & $\begin{array}{c}\text { Constituent Cost } \\
(\mathbf{\%})\end{array}$ \\
\hline 1 & Cement & 390 & $\mathrm{Kg}$ & 0.15 & 58.50 & 53.38 \\
2 & FA (SSD) & 675 & $\mathrm{Kg}$ & 0.01 & 6.75 & 6.16 \\
3 & CA (SSD) & 1031 & $\mathrm{Kg}$ & 0.02 & 20.62 & 18.82 \\
4 & Water & 204.15 & $\mathrm{Kg}$ & 0.01 & 2.04 & 1.86 \\
5 & Conplast SP-430 & 3.90 & $\mathrm{Kg}$ & 5.56 & 21.68 & 19.78 \\
& Total & & & & $\mathbf{1 0 9 . 5 9}$ & $\mathbf{1 0 0}$ \\
\hline
\end{tabular}

Table 4. Production cost for M30 per $\mathrm{m}^{3}$ of GPC.

\begin{tabular}{lcccccc}
\hline S/N & Constituent & $\begin{array}{c}\text { Quantity } \\
\left(\mathbf{k g} / \mathbf{m}^{\mathbf{3}}\right)\end{array}$ & $\begin{array}{c}\text { Unit } \\
\text { Rate } \\
\mathbf{( \$ )}\end{array}$ & $\begin{array}{c}\text { Amount } \\
\mathbf{( \$ )}\end{array}$ & $\begin{array}{c}\text { Constituent Cost } \\
(\mathbf{\%})\end{array}$ \\
\hline 1 & GGBFS/CCA & 390 & $\mathrm{Kg}$ & 0.01 & 3.90 & 4.92 \\
2 & FA (SSD) & 675 & $\mathrm{Kg}$ & 0.01 & 6.75 & 8.52 \\
3 & $\mathrm{CA}$ (SSD) & 1,031 & $\mathrm{Kg}$ & 0.02 & 20.62 & 26.03 \\
4 & $\mathrm{NaOH}_{\text {solution }}$ & 21.24 & $\mathrm{Kg}$ & 1.39 & 29.52 & 37.26 \\
5 & $\mathrm{Na}_{2} \mathrm{SiO}_{3}$ solution & 66.15 & $\mathrm{Kg}$ & 0.26 & 17.20 & 21.71 \\
6 & Water & 122.61 & $\mathrm{Kg}$ & 0.01 & 1.23 & 1.55 \\
& Total & & & & $\mathbf{7 9 . 2 2}$ & $\mathbf{1 0 0}$ \\
\hline
\end{tabular}

\subsection{Economy Index (EI)}

Table 5 shows the economy index of both PCC and GPC, and from the results, control concrete (PCC) has an economy index of 0.320. All geopolymer concretes produced indicate higher economy index than the PCC except GPC 5 and GPC 6. This is primarily due to the cost difference between the cement and the source materials (GGBFS and CCA) and the higher strength of GGBFS and CCA-based GPC. The cost of source materials is very less (around 15$20 \%$ of cement) (Rajarajeswari and Dhinakaran 2016). Both GGBFS and CCA are waste materials from steel industries and agricultural produce respectively.

Table 5. Economy index of concretes produced.

\begin{tabular}{|c|c|c|c|c|}
\hline Mix ID & Total Cost/ $\mathbf{m}^{\mathbf{3}}$ (\$) & Compressive Strength (MPa) & EI & \% Increase/Decrease \\
\hline PCC & 109.59 & 35.12 & 0.320 & - \\
GPC 1 & 79.22 & 43.17 & 0.545 & +41.28 \\
GPC 2 & 79.22 & 40.13 & 0.507 & +36.88 \\
GPC 3 & 79.22 & 35.54 & 0.449 & +28.73 \\
GPC 4 & 79.22 & 28.77 & 0.363 & +11.85 \\
GPC 5 & 79.22 & 22.89 & 0.289 & -10.73 \\
GPC 6 & 79.22 & 20.07 & 0.253 & -26.48 \\
\hline
\end{tabular}




\subsection{Regression Model for Compressive Strength and Economy Index of GPC}

General model power 1 in Matlab (2017a) was employed and the result of the regression equation is presented in Figure 1. With respect to compressive strength, the coefficients of determination $\left(\mathrm{R}^{2}\right)$ is $99.99 \%$ for the economy index at 28 days curing. This concludes that the model is $100 \%$ significantly fit to predict the relationship and also, compressive strength largely depends on the economy index at $95 \%$ confidence bounds.

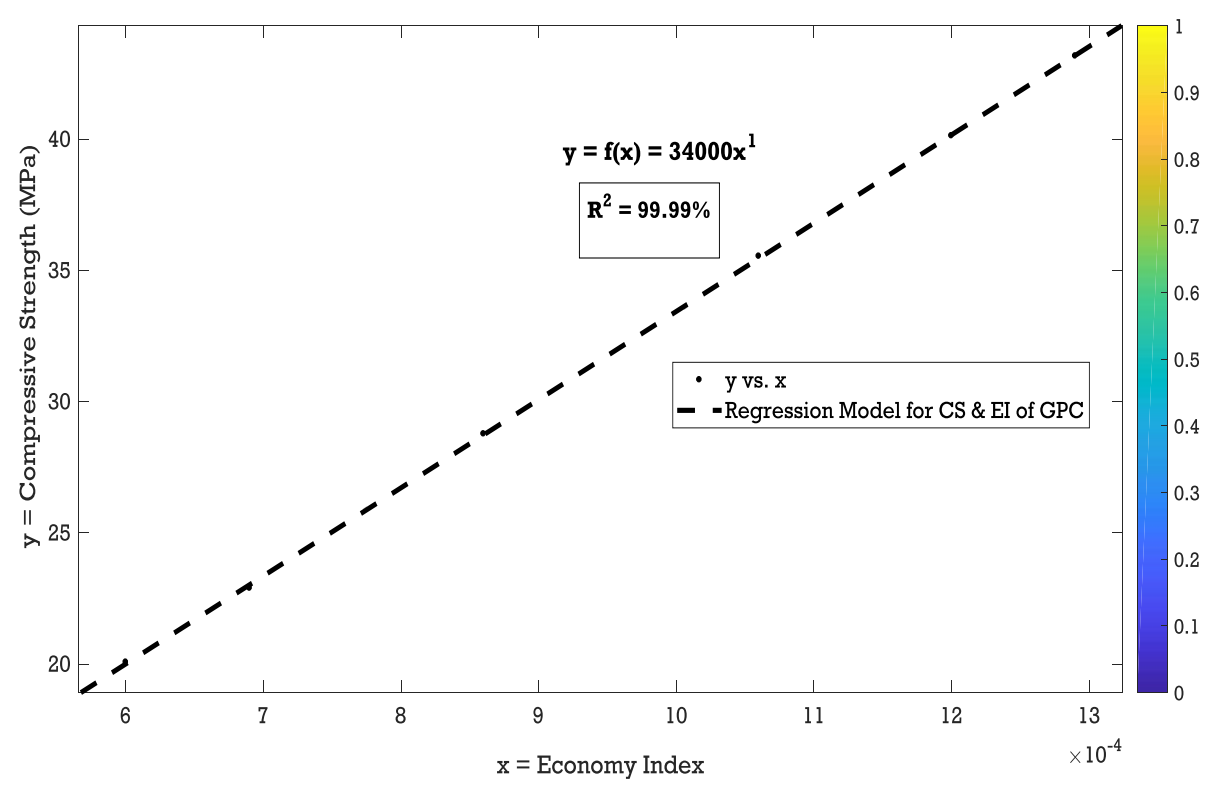

Figure 1. Regression model for compressive strength (MPa) against an economy index.

\section{CONCLUSIONS AND RECOMMENDATIONS}

Based on the above findings, it is concluded that a higher economy index and a lesser cost of production exist in the production of Grade M30 for GPC activated with sodium hydroxide $(\mathrm{NaOH})$ and sodium silicate $\left(\mathrm{Na}_{2} \mathrm{SiO}_{3}\right)$ solutions at ratio 2.5:1 of $\mathrm{Na}_{2} \mathrm{SiO}_{3}$-to-NaOH for 12 molar concentration of $\mathrm{NaOH}$ when compared with PCC of the same grade of concrete. And accordingly, the study contributed to the evaluation of sustainable concrete production and cost implication in comparison with Portland cement concrete. Moreover, the study developed a regression model equation and predicted the relationship between the compressive strength and the economy index. It is therefore recommended that standard specifications and procedures should always be followed in the course of evaluating the production cost for the geopolymer concrete. Economy index of a higher grade of concrete may also be determined to get the higher economy index.

\section{Acknowledgements}

The authors value the Covenant University management for the technical and financial supports in course of the study. 


\section{References}

ACI 211.1, Standard Practice for Selecting Proportions for Normal, Heavyweight, and Mass Concrete, American Concrete Institute Committee, Farmington Hills, USA, 2002.

ACI 214R, Guide to Evaluation of Strength Test Results of Concrete, American Concrete Institute Committee, Farmington Hills, USA, 2011.

BS EN 12390-3, Testing Hardened Concrete: Compressive Strength of Test Specimens, British Standard Institution, 2 Park Street, London. 2000.

Chindaprasirt, P. W. C., Effect of Sodium Hydroxide Concentration on Chloride Penetration and Steel Corrosion of Fly Ash-Based Geopolymer Concrete Under Marine Site, Construction and Building Materials, 63, 303-310, 2014.

Daniel, G., Kong, L., and Sanjayan. J., Effect of Elevated Temperatures on Geopolymer Paste, Mortar And Concrete, Cement and Concrete Research, 40, 334-339, 2010.

Davidovits, J., Geopolymer Cement: A Review, 2013. Retrieved from http://www.geopolymer.org/library/technical-papers/21-geopolymer-cement-review on August 20, 2018.

Lloyd, N., and Rangan, B. V., Geopolymer Concrete with Fly Ash, Second International Conference on Sustainable Construction Materials and Technologies, 2010.

Malathy, R., Fresh and Hardened Properties of Geopolymer Concrete and Mortar, 2009. Retrieved from www.schleibinger.com/cmsimple/?download=r2009 malathy geopolymer.pdf on March 5, 2018.

Ofuyatan, O., Adeola, A., Sulymon, N., Ede, A., Oyebisi, S., Alayande, T., and Ogundipe, J., PseudoDynamic Earthquake Response Model of Wood-Frame with Plastered Typha (Minima) Bale MasonryInfill, International Journal of Civil Engineering and Technology, 9(2), 27-35, February, 2018a.

Ofuyatan, O., Ede, A., Olofinnade, R., Oyebisi, S., Alayande, T., and Ogundipe, J., Assessment of Strength Properties of Cassava Peel Ash-Concrete, International Journal of Civil Engineering and Technology, 9(1), 965-974, January 2018b.

Oyebisi, S. O., Olutoge, F. A., Ofuyatan, M. O., and Abioye, A. A., Effect of Corncob Ash Blended Cement on the Properties of Lateritic Interlocking, Progress in Industrial Ecology-An International Journal, 11(4), 373-387, 2017.

Oyebisi, S., Ede, A., Ofuyatan, O., Oluwafemi, J., and Akinwumi, I., Comparative Study of Corncob Ash Based Lateritic Interlocking and Sandcrete Hollow Blocks, International Journal of Geomate, 15(51), 209-216, November 2018a.

Oyebisi, S., Ede, A., Olutoge, F., Ofuyatan, O., and Oluwafemi, J., Modeling of Hydrogen Potential and Compressive Strength of Geopolymer Concrete, International Journal of Civil Engineering and Technology, 9(7), 671-679, July 2018b.

Oyebisi, S., Ede, A., Olutoge, F., Ofuyatan, O., and Oluwafemi, J., Influence of Alkali Concentrations on the Mechanical Properties of Geopolymer Concrete, International Journal of Civil Engineering and Technology, 9(8), 734-743, August 2018c.

Raheem, A. A., Oyebisi, S. O., Akintayo, S. O., and Oyeniran, M. O., Effects of Admixture on the Properties of Corncob Ash Cement Concrete, Leonardo Electronic Journal of Practices and Technologies, 16, 13-20, January-June 2010.

Rajamane, N. P., and Jeyalakshmi, R., Quantities of Sodium Hydroxide Solids and Water to Prepare Sodium Hydroxide Solution of given Molarity for Geopolymer Concrete Mixes, Indian Concrete Institute Technical Paper, SRM University, India, 2014.

Rajarajeswari, A., and Dhinakaran, G., Compressive Strength of GGBFS based GPC under Thermal Curing, Construction and Building Materials, 126, 552-559, 2016.

Saurabh D., and Yogesh, S., Comparison of Geopolymer Concrete based on Strength and Cost with Concrete, Imperial Journal of Interdisciplinary Research (IJIR), 3(9), 1026-1029, 2017.

Thaarrini, J., and Dhivya, S., Comparative Study on the Production Cost of Geopolymer and Conventional Concretes, International Journal of Civil Engineering Research, 7(2), 117-124, 2016. 